\title{
Erratum: People
}

Nature Biotechnology 25, 692 (2007); published online 1 June 2007; corrected after print 8 August 2007

In the version of this article initially published, Anne Wojcicki was incorrectly referred to as Dr. Wojcicki rather than Ms. Wojcicki.

\section{Corrigendum: Therapeutic targeting of a stem cell niche}

Nature Biotechnology 25, 238-243 (2007); published online 21 January 2007; corrected after print 8 August 2007

In the version of this article initially published online 21 January 2007, the $y$-axes of Figures $1 \mathrm{e}, 2 \mathrm{c}$ and $2 \mathrm{~d}$ are labeled incorrectly. They should be labeled “\% CD45.1 in PB." The error has been corrected for all versions of the article. 